\title{
Dampak Krisis Keuangan Global terhadap Perbankan di Indonesia: Perbandingan antara Bank Konvensional dan Bank Syariah
}

\author{
Oleh: Heri Sudarsono ${ }^{1}$
}

\begin{abstract}
Abstact
This article traces to analyze the impact of global financial crisis to Indonesian banking condition, a comparison between shari'ah and conventional bank. It starts with description about the root of financial crisis and its impact to Indonesian financial sector. Both shariah and conventional bank face the effects of the crisis and react to Bank Indonesia policy. As Bank Indonesia raises BI rate, conventional bank increases its interest as response to policy which mean businessmen have to pay higher for money they borrow from bank. Such a condition makes businessmen move to shari'ah bank in which its profit and losing share financing system make them pay the same amount as they borrow. The article concludes that sharia banking is stronger than conventional bank in facing financial crisis.
\end{abstract}

Keywords: global financial crisis, shariah and conventional bank

\section{Pendahuluan}

Krisis keuangaan yang terjadi di Amerika Serikat (AS) ternyata telah mempengaruhi wajah keuangan global. Negara-negara di wilayah Eropa seperti Islandia, Rusia, Belanda, Inggris, Perancis, Jerman, demikian juga dengan di wilayah Asia-Pasifik, seperti Cina, Taiwan, Singapura, Philipina, Jepang, dan Australia terkena dampak krisis. Dampak krisis yang dihadapi negara-negara tersebut pada umum adalah meningkatnya inflasi, turunnya nilai tukar, turunnya pertumbuhan ekonomi, runtuhnya indeks bursa dan sejumlah bank/institusi keuangan/korporasi mengalami kesulitan keuangan atau bangkrut.

Dampak langsung krisis keuangan ini bagi Indonesia adalah kerugian beberapa perusahaan di Indonesia yang berinvestasi di institusi-institusi keuangan Amerika Serikat. Perusahaan keuangan ataupun non bank yang mengalokasikan dana pada sumber pendapatan alternatif, melalui pembelian saham atau obligasi pada instrumen keuangan asing, seperti Citigroup, UBS, Merril Lynch, Morgan Stanley, Lehman Brothers, Fannie Mae, Freddie Mac, American International Group (AIG) dan lainnya.

Sedangkan dampak tidak langsung dari krisis adalah turunnya likuiditas, melonjaknya tingkat suku bunga, turunnya harga komoditas, melemahnya nilai tukar rupiah, dan melemahnya pertumbuhan sumber dana. Demikian juga, menurunnya tingkat kepercayaan konsumen, investor, dan pasar terhadap berbagai institusi keuangan yang menyebabkan melemahnya pasar modal.

${ }^{1}$ Dosen Tetap Fakultas Ekonomi, Universitas Islam Indonesia (UII) Email: heri.sudarsono@gmail.com 
Heri Sudarsono: Dampak Krisis Kenangan Global...

Krisis keuangan juga mengurangi pasokan likuditas sektor keuangan karena bangkrutnya beberapa institusi keuangan global khususnya bank-bank investasi yang berpengaruh pada aliran kas perusahaan-perusahaan di Indonesia. Keadaan ini akan menyebabkan naiknya tingkat suku bunga dan turunnya pendanaan ke pasar modal dan perbankan global.

Sesungguhnya turunnya nilai rupiah ini bisa meningkatkan nilai ekspor, namun krisis keuangan menyebabkan turunnya permintaan komoditas dari luar negeri. Turunnya ekspor mengurangi pendapatan negara sehingga jika tidak diimbangi dengan turunnya pengeluaran dollar melalui penurunan tingkat impor akan menyebabkan defisit perdagangan. Defisit perdagangan mempersulit modal masuk seiring dengan keringnya likuiditas pasar keuangan global. Selain itu, kenaikan impor di saat pasar ekspor stagnan akan menekan kenaikan cadangan devisa dan berarti akan memunculkan ekspektasi gejolak depresiasi rupiah. Juga, kemerosotan akan mengacaukan dan menurunkan produksi dalam negeri yang juga berakibat pengurangan pekerja atau peningkatan pengangguran.

Untuk mengatasi dampak krisis ini, BI menempuh beberapa langkah, yaitu memperkuat likuiditas sektor perbankan, menjaga pertumbuhan kredit pada tingkat yang sesuai untuk mendukung target pertumbuhan ekonomi, dan kebijakan terkait neraca pembayaran. Kebijakan yang dijalankan adalah memperkuat sektor perbankan untuk mengantisipasi dampak pengeringan likuiditas global, untuk mendukung pertumbuhan ekonomi diupayakan pertumbuhan kredit dijaga pada level yang tetap, dan mencari pembiayaan untuk mengurangi defisit anggaran pendapatan dan belanja negara dari sumber non pasar, seperti sumber-sumber bilateral maupun multilateral. ${ }^{2}$

Bank Indonesia dan Pemerintah, termasuk Lembaga Penjaminan Simpanan memperkuat protokol implementasi jaring pengamanan sektor keuangan (JPSK) atau financial safety net dan peran lender ofthe last resort dengan tetap memperhatikan aspek governance, sehingga terdapat mekanisme yang lebih baik dalam menghadapi krisis likuiditas perbankan dan obligasi. Berkaitan dengan hal tersebut pemerintah mendorong percepatan pembahasan UU JPSK. Selain itu, pemerintah mengeluarkan Perpu tentang Perubahan Kedua Atas UU Nomor 3 Tahun 2004 tentang BI dan Perpu tentang Perubahan Atas UU Nomor 25 Tahun 2004 tentang LPS. ${ }^{3}$

Kebijakan lain yang ditempuh Bank Indonesia adalah menyederhanakan aturan Giro Wajib Minimum (GWM) untuk menambah kepercayaan diri bank terhadap kondisi likuiditas perbankan yang melemah akibat krisis keuangan global. Giro Wajib Minimum (statutory reserve) adalah simpanan minimum yang harus

${ }^{2}$ Di kawasan Eropa dan Asia-Pasifik penanggulangan krisis melalui penurunan atau kenaikan suku bunga, nasionalisasi perusahaan, mengambil alih untuk penyehatan, bailout, membeli kembali saham, insentif bagi eksportir, penutupan bursa, meningkatkan jaminan deposito dan melarang short selling.

${ }^{3}$ Rancangan Undang-Undang Jaring Pengaman Sektor Keuangan (JPSK) atau Financial Safety Net merupakansuatu dasar hukum untuk mengantisipasi ketahanan sistem keuangan. RUU JPSK merupakan payung hukum bagi otoritas, Pemerintah dan Bank Indonesia, ketika harus mengambil tindakan darurat dalam rangka menyelamatkan perekonomian nasional.Undang-Undang JPSK digunakan agar jelas tata cara pengambilan keputusan mengenai kesulitan keuangan bank yang berdampak sistemik serta pemberian fasilitas pembiayaan darurat bersumber pada pendanaan yang berasal dari APBN. 
Heri Sudarsono: Dampak Krisis Kenangan Global...

dipelihara oleh bank dalam bentuk saldo rekening giro pada Bank Indonesia yang besarnya ditetapkan oleh Bank Indonesia sebesar persentase tertentu dari Dana Pihak Ketiga (DPK) bank. Selain itu, Bank Indonesia juga membuka ruang untuk repo Surat Utang Negara (SUN) atau SBI yang diperpanjang masa berlakunya hingga tiga bulan.

Kebijakan pemerintah di bidang moneter telah dikeluarkan dalam rangka mengantisipasi dampak krisis keuangan pada sektor perbankan. Bagaimana dampak krisis keuangan dan dampak kebijakan moneter terhadap perkembangan bank kovensional dan bank syariah? Dan, apa perbedaan respon bank konvensional dan bank syariah dalam mengatasi krisis keuangan? Paper ini mengungkapkan secara deskriptif melalui data keuangan Bank Indonesia (BI) dengan membandingkan dampak krisis keuangan global bagi perbankan konvensional dan perbankan syariah Indonesia.

\section{Awal Terjadinya Krisis}

Rekayasa instrumen keuangan yang berbentuk subprime mortgage menjadi salah satu sebab timbulnya krisis ekonomi di AS. Subprime mortgage atau surat kredit perumahan (KPR) yang berbunga rendah di tahun 2001-2005 menyebabkan meningkatnya permintaan rumah (boom in the housing market). Rendahnya tingkat suku bunga di tahun tersebut dikarenakan Bank Sentral AS mengantisipasi kelesuan investasi karena dampak runtuhnya saham-saham teknologi (burst of internet bubble) pada Maret 2000.

Rezim suku bunga yang rendah pada tahun 2001-2005 mendorong masyarakat AS cenderung menjadi konsumtif tetapi dengan mengandalkan pembiayaan dari pinjaman yang menjadi utang ke bank-bank. Rendahnya tingkat suku bunga ini juga mendorong peningkatan ekspansi perusahaan dan mendorong terciptanya instrumen keuangan yang mempunyai resiko tinggi dengan pendapatan tinggi (bigher risk higher return) atas dasar salah satu prinsip investasi keuangan (financial investments) yaitu lower risk. lower return dan higher risk. higher return. ${ }^{4}$

Subprime mortgage merupakan surat kredit yang bisa diperjualbelikan oleh pemberi mortgage (mortgage lenders) kepada pihak lain (debt collateral swap) dengan bunga tertentu, seperti bank komersial. ${ }^{5}$ Bank komersial kemudian menjual sebagai portfolio mortgage tersebut kepada invesment bank. Oleh pihak invesment bank, subprime mortgage tersebut disekuritisasikan (securitization) dalam bentuk mortgage backed securities (MBS). ${ }^{6}$

${ }^{4}$ Selain itu, rendahnya tingkat bunga menyebabkan perbankan dan lembaga keuangan bukan bank di AS dan dunia terlibat pada instrumen keuangan yang beresiko. Dan, tingkat bunga rendah menyebabkan dana mengalir ke negara-negara yang mempunyai suku bunga tinggi dalam bentuk investasi keuangan pada securities berupa saham dan surat berharga utang, walaupun resiko negara (country risk) dan resiko kurs lebih tinggi.

${ }^{5}$ Lihat Miskhin (1997) dalam The Causes and Propagation of Financial Instability: Lessons for Policymakers di Federal Reserve Bank of Kansas City (1937), Maintaining Financial Stability in a Global Economy, Proceedings of a Symposium Sponsored by the FRB Kansas City, Jackson Hole, Wyoming, August 28-30, 1997.

${ }^{6}$ Menurut Joseph E. Stiglitz (2003), CEO (Chief Executive Officer) dan eksekutif korporasi telah melakukan rekayasa gaji dengan pertimbangan yang tidak jelas dan lebih parah lagi dengan adanya praktek memberikan stock option (hak opsi saham) dimana para eksekutif mempunyai hak membeli saham perusahaan milik sendiri di bawah harga pasar. 
Heri Sudarsono: Dampak Krisis Kenangan Global...

Mortgage backed securities (MBS) merupakan aset yang memiliki pendapatan, yaitu ketika peminjam mortgage membayar bunga. MBS dapat dipilah-pilah menjadi beberapa tranches dengan tingkat senioritas yang berbeda. MBS bersama instrumen uang lainnya bisa diturunkan (derivative) lagi menjadi collateral debt obligations (CDO). CDO juga dipilah-pilah lagi menjadi beberapa tranches dengan senioritas berbeda. ${ }^{7}$ Nilai CDO yang menguntungkan dengan bunga yang murah diminati oleh berbagai bank, asuransi, hedge fund, dan mutual fund. ${ }^{8}$

Nilai derivatif dari subprime mortgage bisa berlipat-lipat atau jauh dari nilai riil perumahan yang digunakan sebagai jaminan. Proses sekuritisasi ini menimbulkan bubble yang rawan terhadap gejolak ekonomi karena nilainya tidak ekuivalen dengan jaminan riil (underlying asset). Kerapuhan sistem keuangan ini terbukti ketika pada tahun 2004 Bank Sentral AS meningkatkan target suku bunga (credit tightening) secara berlahan. Kenaikan tingkat bunga membebani pembayaran mortgage yang mengunakan tingkat bunga mengambang, tingkat bunga referensi $+\mathrm{x} \%$.

Kenaikan tingkat bunga menjadikan konsumen mengalami kesulitan untuk membayar bunga mortgage. Apalagi untuk jenis subprime mortgage yang memiliki kualifikasi sebagai sebagai surat utang beresiko dengan tingkat bunga yang lebih tinggi dibanding prime mortgage. Kenaikan tingkat bunga ini menjadikan nasabah mulai kesulitan membayar utang sehingga banyak rumah akhirnya disita oleh bank karena pemiliknya default. ${ }^{9}$

Keadaan ini juga digunakan spekulan untuk menjual rumah yang memang awal mulanya dibeli dengan harga murah. ${ }^{10}$ Ini juga meningkatkan resiko kredit macet (non performing loan) bank yang mempengaruhi rendahnya kesehatan likuditas bank sehingga tidak memenuhi rasio kecukupan modal, capital adequacy rasio (CAR). Kondisi ini yang menyebabkan kepercayaan nasabah menurun sehingga menarik dananya dengan jumlah yang besar.

Kebutuhan likuiditas ini yang menjadikan pihak bank menjual rumah sitaaan dengan harga rendah. Ketidakmampuan pihak perbankan untuk mendapatkan laba yang optimal menganggu pembayaran derivative dari subprime mortgage sehingga menganggu kepercayaan investor. ${ }^{11}$ Akhirnya, supaya tidak meruntuhkan likuiditas yang lebih parah, investor yang terdiri dari perusahaan besar yang anak cabangnya

${ }^{7}$ Alan Greenspan menyalahkan sekuritisasi ini, yang mengakibatkan krisis keuangan global bukan karena disebabkan utang semata-mata. Lihat Alan Greenspan (2008), Greenspan Sees Signs of Credit Crising Easing, Stock \& Economy-MSNBC. Disamping itu moral hazard juga menjadi sebab terjadinya krisis lihat Holden Lewis (2007), Moral Hazard Help Shape Mortgage Mess, di www.bankrate com.

${ }^{8}$ Lihat juga di Atif Mian dan Amir Sufi (2008) dalam The Consequences of Mortgage Credit Expansion: Evidence from the 2007 Mortgage Default Crisis, January (htt://ssrn. com/ abstract = 1072304).

${ }^{9}$ Karena tingginya resiko subprime mortgage maka subprime mortgage digambarkan sebagai ninja loans atau dalam kondisi nasabah yang no income, no job, and no assets. Lihat Yulita Demyanyk and Otto Van Hemert (2008), Understanding the Subprime Mortgage Crisis, Working Paper Series. Social Science Electronic Publishing.

${ }^{10}$ Lihat H.P Minsky (2008), Economist Who Decode Lending Trends, New York Times, , www.nytimes.com diakses pada 3 Juli 2008. Di samping itu sektor konsumtif, bukan produktif lebih dominan dalam mempengaruhi pertumbuhan kredit, dalam bukunya The Roaring Nineties: A New History of the World's Most Prosperous Decade, Joseph E. Stigliz (2003), mengatakan bahwa mayoritas yang meminjam uang di sektor keuangan adalah pegawai, bukan petani.

${ }^{11}$ Krisis keuangan ini juga mengindikasikan Credit Rating Agencies (agen yang ditunjuk untuk menilai sekuritas, MBS dan CDO) dibayar oleh perusahaan yang mengorganisir dan menjual utang kepada investor, seperti halnya investment bank. Lihat Subprime Crisis, di www.wikipedia.com. 
Heri Sudarsono: Dampak Krisis Kenangan Global...

menjangkau seluruh dunia, ketika melihat gejala menurunnya nilai instrumen derivative ini menjual efeknya dengan harga yang rendah. Namun beberapa perusahaan yang terlambat mengantisipasi hal tersebut akhirnya bangkrut karena hasil penjualan derivative tidak memenuhi kebutuhan likuiditasnya Keadaan ini mengoncang pasar bursa AS dan Eropa sampai akhirnya di kawasan Asia.

\section{Dampak bagi Sektor Keuangan Indonesia}

Setelah Lehman Brothers menyatakan bangkrut pada September 2008, dampak krisis subprime mortgage pada perekonomian global mulai menyebar. Adapun dampak krisis tersebut bagi perekonomian Indonesia, ditandai dengan adanya penarikan dana dalam valas khususnya dolar AS oleh lembaga-lembaga keuangan kreditor dan investor di AS. Penarikan tersebut dilakukan dengan menjual sekuritas saham dan surat berharga utang yang dibeli sebelumnya dalam rupiah kemudian dibelikan dolar. Juga penarikan dana dilakukan dengan mencairkan dana yang telah ditempatkan pada bank-bank di Indonesia dan langsung dalam dolar.

Krisis keuangan ini menyebabkan dana yang direpatriasi berjumlah besar sehingga menimbulkan penjualan saham dan surat berharga utang dalam jumlah yang besar. Keadaan ini menjadikan harga sekuritas saham dan surat berharga utang akan turun sehingga indeks harga saham turun tajam. Hitungan suku bunga bagi surat berharga utang yang membayar pendapatan tetap (fixed income securities) akan naik. Penurunan harga sekuritas akan menimbulkan kerugian (capital loss) sehingga modal perusahaan dan rasio kecukupan modal atau capital adequacy ratio (CAR) menipis.

Turunnya kepercayaan terhadap pasar domestik menyebabkan permintaan terhadap dolar naik signifikan, yang berarti mengakibatkan nilai dolar terhadap rupiah naik. Depresiasi rupiah tidak saja disebabkan langsung oleh penarikan dana tersebut di atas, tetapi juga berpotensi diperparah karena lebih besar dari tingkat depresiasi mata uang di luar dolar. Depresiasi hampir semua mata uang di luar dolar karena dolar ditarik kembali untuk memback-up likuditas perusahaan AS. Keadaan ini menjadikan dolar semakin mahal karena dolar semakin langka dan permintaan dolar pun akhirnya meningkat.

Gejolak kurs akan berdampak pada kenaikan harga atau inflasi menjadi tinggi, serta sebagai dasar rasional terus timbulnya ekspektasi inflasi tinggi (the expectation of high inflation) yang pada gilirannya akan direalisasikan pada kenaikan harga atau inflasi terus meninggi dan timbulnya gejolak kurs. Keadaan ini menimbulkan keinginan melakukan currency substitution dari rupiah ke dolar. Apalagi kecenderungan ini dikaitkan dengan ekspektasi inflasi di Indonesia yang cukup tinggi dalam dua angka (double digits). Dalam kondisi seperti ini, semua kemungkinan ekonomi dapat berpotensi mengakibatkan gejolak rupiah terhadap dolar.

Gejolak kurs dan ekpektasi gejolak depresiasi rupiah yang besar dapat menyebabkan dana masyarakat berpindah atau lari ke bank yang berkualitas tinggi dan bank asing di dalam negeri dan di luar negeri (currency substitution). Gejolak itu juga akan mengakibatkan debitur bank mengalami kesulitan usaha, dengan konsekuensi selanjutnya tidak mampu bayar pokok utang dan bunga ke bank. 
Heri Sudarsono: Dampak Krisis Kenangan Global...

Akibatnya, bank mengalami kesulitan likuiditas dan menyebabkan meningkatnya cost of fund sehingga bank tidak bisa memenuhi kewajibannya kepada Dana Pihak Ketiga (DPK). ${ }^{12}$

Ekspor non-migas Indonesia berpotensi tertekan dan merosot. Potensi ini berkaitan dengan melemahnya ekonomi AS dan negara-negara industri, sebagai dampak dari krisis keuangan AS. Di AS, dampak lanjut dari krisis subprime mortgage telah dan akan terus membatasi pembiayan dari perbankan ke sektor riil dan usaha sektor keuangan, serta menekan pengeluaran belanja para konsumen.

Dampak bagi perbankan Indonesia dengan adanya penarikan dana oleh investor luar negeri di berbagai perusahaan Indonesa mengakibatkan bank mengalami krisis likuiditas, penurunan nilai aktiva produktif (earning assets) dalam bentuk kredit dan surat berharga yang dibeli bank, penurunan kecukupan modal (CAR) terutama karena kerugian berasal dari pencadangan atas penurunan kualitas aktiva produktif dan gagal bayar bunga kredit.

Pengalaman krisis keuangan tahun 1998-2003 telah membawa dunia perbankan Indonesia mampu bertahan dalam krisis 2008. Hal ini dikarenakan krisis 1998 telah mempengaruhi perbaikan pada beberapa aspek, antara lain transparansi yang memenuhi akuntabilitas dan efektifitas, profesionalisme dan kompetensi, pemenuhan ketentuan perbankan dan prinsip kehati-hatian. Demikian juga, bank tidak lagi berperanan sebagai kasir dari sejumlah perusahaan dan grup perusahaan tertentu, terpeliharanya posisi eksposur (exposure) valas tanpa resiko (long or square foreign exchange net open position) yang terkandung pada neraca bank, suasana persaingan antar bank sehat baik yang bercirikan oligopoli untuk antar bank besar dan monopolistic competition bagi bank menengah ke bawah.

\section{Pengaruh Krisis pada Bank Syariah dan Bank Konvensional}

Krisis keuangan menyebabkan Bank Indonesia meningkatkan BI rate untuk meredam inflasi yang diakibatkan oleh turunnya nilai rupiah terhadap dolar. Kenaikan BI rate direspon dengan kenaikan tingkat bunga bank konvensional secara masif. Namun kenaikan tingkat bunga ini tidak mempengaruhi bank syariah secara langsung. Sistem jual beli (bai) di bank syariah, dimana pembayaran margin didasarkan fixed rate dimana ketetapan didasarkan kontrak tidak bisa berubah sewaktu-waktu seperti hanya dengan bunga. ${ }^{13}$ Namun bagi produk bagi hasil dimungkinkan krisis keuangan ini akan mempengaruhi return bank syariah karena krisis keuangaan akan mempengaruhi bagi hasil pegusaha untuk mendapatkan laba optimal.

${ }^{12}$ Kenaikan tingkat bunga Bank Indonesia (BI rate) atas dasar pertimbangan inflasi meninggi dan ekspektasi inflasi akan tinggi. Kebijakan ini dimaksudkan untuk memberi sinyal pengetatan likuiditas di sektor keuangan untuk mengendalikan permintaan agregat (aggregate demand), maupun demi menghalangi usaha pembelian dolar yang dapat mendorong gejolak kurs dan ekspektasi gejolak depresiasi rupiah.

${ }^{13}$ Menurut Umer Chapra (1985), dalam Towards a Just Monetary System: A Discussion of Money, Banking, and Monetary Policy in the Light of Islamic Teachings, London: Islamic Foundation, suku bunga yang tinggi akan (1) menghalangi investasi dan formasi modal; (2) menurunkan produktivitas dan kesempatan kerja; (3) mengurangi laju pertumbuhan usaha. Dan, suku bunga yang rendah akan (1) menyebabkan ketidakadilan pendapatan dan kekayaan; (2) mengurangi rasio tabungan kotor; (3) meningkatkan inflasi; (4) merangsang investasi yang tidak produktif dan spekulatif; (5) menumbuhkan kelangkaan modal dan menjatuhkan kualitas investasi.

Volume III, No. 1, Juli 2009 
Heri Sudarsono: Dampak Krisis Kenangan Global...

Kenaikan tingkat bunga menyebabkan daya tarik menyimpan dana di bank konvensional meningkat, namun kenaikan tingkat bunga ini tidak akan menarik bagi investor yang akan mendapatkan beban bunga yang lebih tinggi. Sementara itu, kenaikan tingkat bunga akan menurunkan minat masyarakat yang menyimpan dana di bank syariah karena tingkat marginnya lebih rendah di banding dengan tingkat bunga simpanan bank konvensional. Namun, bank syariah akan lebih menguntungkan bagi investor dikarenakan margin yang dibebankan pada investor bank syariah lebih rendah dibanding dengan bank konvensional. ${ }^{14}$

Dalam menjaga likuditas, tingkat bunga masih menjadi benchmark bagi bank syariah dalam penentuan tingkat margin dan nisbah bagi hasil bank syariah. Dengan tingkat margin pembiayaan yang lebih rendah dibanding dengan tingkat fee/bagi hasil pada tabungan dan deposito, membuat pembiayaan bank syariah lebih menarik bagi investor dibanding bank konvensional. Keadaan ini akan menyebabkan meningkatnya dana yang keluar untuk pembiayan dari dana pihak ketiga (DPK) yang masuk sehingga konsekuensinya financing deposit rasio (FDR) bank syariah meningkat. Kondisi berbeda ada pada pihak penabung yang akan lari ke bank konvensional karena akan menikmati keuntungan bunga lebih tinggi dibanding dengan bank syariah. Meningkatnya dana keluar akan meningkatkan resiko likuditas bank syariah. Untuk mengatasi keadaan ini, bank syariah perlu meningkatkan rate bonus/fee/bagi hasil untuk giro, tabungan, dan deposito.

Dari data pada tabel 1, dapat diketahui perbandingan tingkat bunga dari dana pihak ketiga dengan pembiayaan bank konvensional dengan bank syariah. Secara umum dapat diketahui bahwa tingkat bunga bank konvensional lebih tinggi dibanding dengan tingkat imbalan, bagi hasil, fee bonus pada bank syariah. Tingginya bagi hasil/fee/bonus untuk tabungan di tahun 2008 dan 2009 menunjukkan bahwa dalam mempertahankan likuidasi bank syariah masih mengandalkan tabungan. Sementara itu, bank konvensional lebih mempertahankan dana-dana berjangka melalui tingkat bunga yang tinggi.

Data pada bagian pembiayaan menunjukkan bahwa tingkat margin murabahah menepati posisi tertinggi di antara tingkat margin/bagihasil/fee/bonus produk pembiayaan yang lain. Sedangkan secara berturut-turut istisna dan mudharabah pada tingkat kedua dan ketiga. Nilai ini lebih rendah dibanding dengan tingkat bunga pinjaman modal kerja, investasi dan konsumsi. Nilai equivalent rate imbalan/bagi hasil/fee/bonus yang lebih rendah dibanding dengan bank konvensional tentu akan menjadikan bank syariah lebih kompetitif

Sebagai bank yang tidak mengunakan bunga, tingkat imbalan/margin/bagi hasil/fee bank syariah lebih rendah dibanding dengan bank konvensional. Mayoritas struktur pembiayaan bank syariah yang mengunakan skim murabahah, dimana tingkat margin ditetapkan di saat akad dilakukan, pada tahun 1998 marginnya

${ }^{14}$ Dalam Islam, uang adalah uang bukan barang yang bisa dijualbelikan. Seperti hanya bukti atas kepemilikan uang dalam bentuk utang atau surat utang tidak dapat diperjualbelikan dengan mensekuritasikan dalam beberapa efek. Utang telah menjadi komoditi yang diperjualbelikan sehingga nilai utang yang awal mulanya didasarkan atas nilai asset (perumahan) menjadi berlipat ganda. Pasar kapitalis menciptakan uang yang tidak di back up asset riil sehingga nilai uang menjadi semu. 
Heri Sudarsono: Dampak Krisis Kenangan Global...

adalah 14.92\% atau naik dari tahun 1997 yang nilainya sebesar 14.66\%. Di lain pihak, tingkat ekuivalen bagi hasil pada mudharabah meningkat di akhir tahun 2008 menjadi $19.38 \%$ dari tahun sebelumnya, $16.93 \%$. Kenaikan margin dan bagi hasil pada produk bank syariah ini merupakan usaha untuk menghindari persoalan likuiditas diakibatkan dari krisis keuangan global yang memicu naiknya tingkat bunga perbankan nasional.

Tingkat margin dan bagi hasil pembiayaan bank syariah relatif lebih tinggi dibanding dengan rata-rata tingkat bunga kredit bank konvensional. Hal sama terjadi pada tingkat bonus/bagi hasil pada tabungan dan deposito bank syariah yang meningkat walaupun kenaikan pada tahun 2009 masih dibawah tingkat bunga tabungan dan deposito bank konvensional. Rendahnya tingkat bagi hasil bank syariah ini menyebabkan turunnya minat nasabah untuk menyimpan dananya pada bank syariah. Sementara itu, pada saat yang sama tingkat margin dan bagi hasil pada pembiayaan bank syariah lebih tinggi daripada bank konvensional sehingga menyebabkan nasabah cenderung lebih tertarik untuk mengajukan pinjaman ke bank konvensional.

Tabel 1. Ekuivalen Tingkat Imbalan/Bagi hasil/Fee/Bonus Bank Syariah dan Tingkat Bunga Bank Konvesional

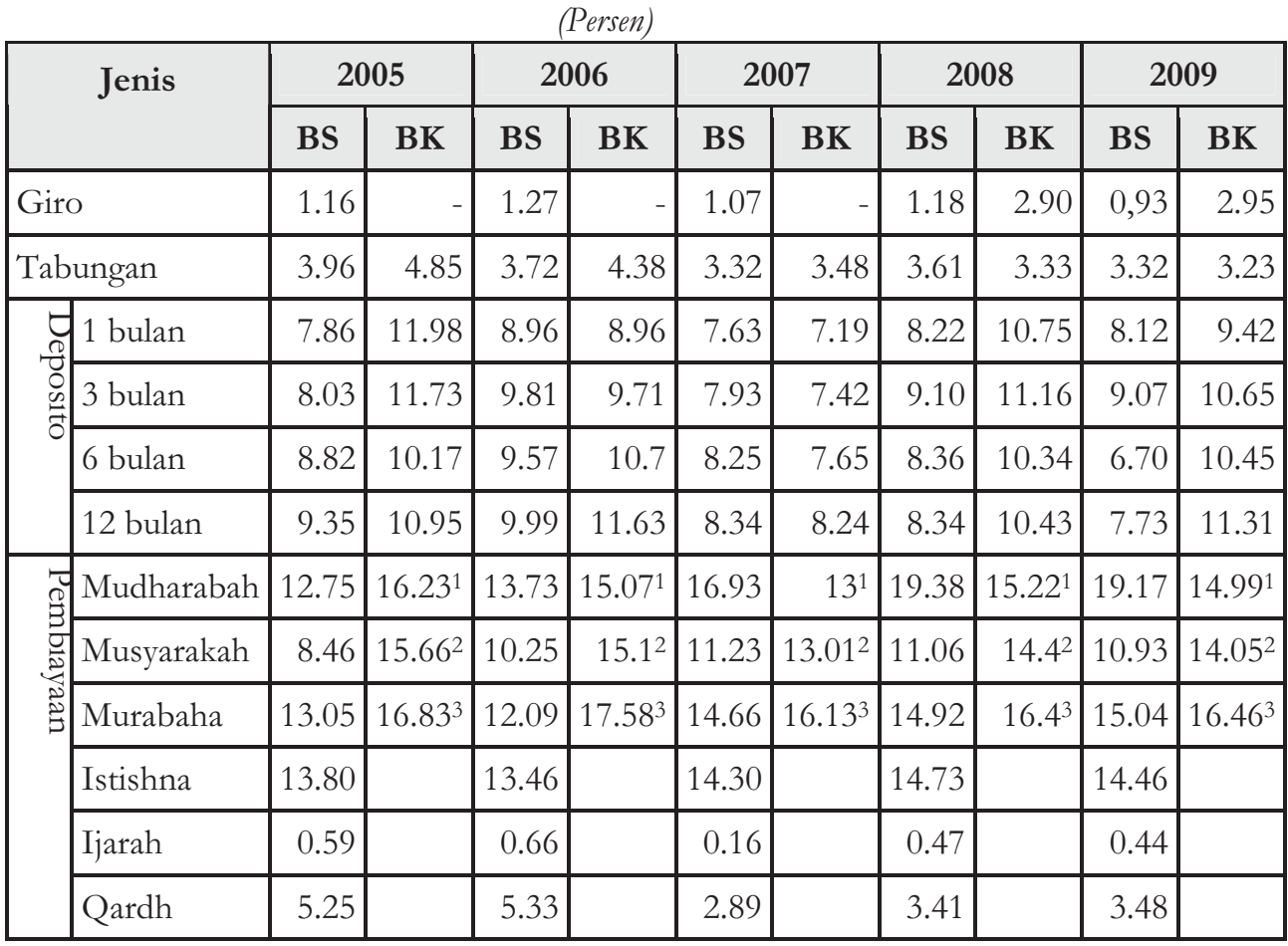

Catatan: BS adalah Bank Syariah dan BK adalah Bank Konvensional; (1) keredit modal kerja (2) kredit investasi (3) kredit konsumsi pada bank umum konvesional; tahun 2009 mengunakan data Maret 2009. Sumber: Bank Indonesia, 2009. 
Heri Sudarsono: Dampak Krisis Kenangan Global...

Tabel 2 menunjukkan bahwa nilai DPK atau deposit bank syariah naik cukup pesat dari tahun 2005 sampai 2009. Sumbangan terbesar pendanaan pada bank syariah dari deposito, sementara itu tabungan dan giro menempati urutan kedua dan ketiga. Tingginya minat nasabah untuk menyimpan dalam bentuk simpanan berjangka dikarenakan keamanan dana dan tingkat bagi hasil yang tinggi. Sementara itu, jumlah nilai giro, tabungan dan deposito bank konvensional lebih banyak jumlahnya dibanding bank syariah. Besarnya nilai DPK ini lebih banyak dipengaruhi oleh bank konvensioanl yang lebih dahulu dikenal nasabah, jumlah banknya lebih banyak dari bank syariah, dan tingkat bunga kreditnya lebih rendah di banding dengan bank syariah.

Tabel 2. Perbandingan Deposit Funds dan Financing antara Bank Syariah dan Bank. Konvesional (Miliar Rupiab)

\begin{tabular}{|c|c|c|c|c|c|c|}
\hline \multicolumn{7}{|c|}{ Jumlah Rekening Bank Umum Syariah dan Unit Usaha Syariah } \\
\hline & & 2005 & 2006 & 2007 & 2008 & 2009 \\
\hline \multirow{4}{*}{$\begin{array}{l}\text { Deposit } \\
\text { Funds }\end{array}$} & Giro & 2.048 & 3.416 & 3.750 & 4.238 & 4.753 \\
\hline & Tabungan & 4.367 & 6.430 & 9.454 & 12.471 & 12.624 \\
\hline & Deposito & 9.169 & 10.826 & 14.807 & 20.143 & 21.274 \\
\hline & Total & 15.584 & 20.672 & 28.012 & 36.852 & 38.651 \\
\hline \multirow[t]{4}{*}{ Financing } & Modal Kerja & 7.988 & 10.405 & 15.656 & 20.554 & 20.421 \\
\hline & Investasi & 4.288 & 4.374 & 5.637 & 7.907 & 8.171 \\
\hline & Konsumsi & 2.956 & 5.666 & 6.652 & 9.734 & 10.251 \\
\hline & Total & 15.232 & 20.445 & 27.944 & 38.201 & 38.843 \\
\hline \multicolumn{7}{|c|}{ Jumlah Rekening Bank Umum Konvensional } \\
\hline \multirow{4}{*}{$\begin{array}{l}\text { Deposit } \\
\text { Funds }\end{array}$} & Giro & 193.854 & 249.564 & 309.335 & 307.743 & 306.440 \\
\hline & Tabungan & 281.268 & 333.873 & 434.480 & 476.717 & 459.459 \\
\hline & Deposito & 455.038 & 510.008 & 540.982 & 675.983 & 710.330 \\
\hline & Total & 930.160 & 1.093 .445 & 1.284 .797 & 1.460 .443 & 1.476 .229 \\
\hline \multirow[t]{4}{*}{ Financing } & Modal Kerja & 354.557 & 414.749 & 533.240 & 684.672 & 671.611 \\
\hline & Investasi & 134.400 & 151.209 & 196.218 & 255,900 & 262.091 \\
\hline & Konsumsi & 206.691 & 226.339 & 282.553 & 367,117 & 371.688 \\
\hline & Total & 695.648 & 792.297 & 1.036 .065 & 1.289 .839 & 1.305.389 \\
\hline
\end{tabular}

Catatan: tahun 2009 mengunakan data Maret 2009. Sumber: Bank. Indonesia, 2009. 
Heri Sudarsono: Dampak Krisis Kenangan Global...

Tingginya tingkat margin dan bagi hasil pada bank syariah lebih dikarenakan adanya sejumlah faktor. Faktor yang pertama adalah sebagai lembaga keuangan yang keberadaannya relatif baru membutuhkan biaya (overhead cost) yang cukup tinggi. Biaya-biaya itu dikeluarkan untuk membangun kantor, fasilitas kantor, penataan sistem, dan pelatihan tenaga kerja. Faktor kedua adalah tingginya inflasi yang menjadi faktor dalam menentukan tingkat imbalan/fee/bonus/ bagi hasil. Faktor ketiga adalah tingkat bunga yang mempengaruhi tingkat imbalan/fee/bonus/bagi hasil sebagai konsekuensi supaya tidak kehilangan nasabah. Dan faktor keempat adalah secondary market berprinsip syariah sebagai sumber pendapatan alternatif bank syariah yang juga mempengaruhi nilai imbalan/fee/bonus/bagi hasil.

Sementara dalam Tabel 3., tingkat rasio bank syairah dan bank konvensional menunjukkan nilai yang berbeda. Tingkat ROA, ROE, NPF, dan BOPO bank konvensional lebih tinggi dibanding bank syariah. Rata-rata rasio laba terhadap asset dan modal bank syariah lebih rendah dibanding dengan bank konvensional dari tahun 2005 sampai 2009. Di tahun 2008, krisis keuangan menyebabkan ekspor menurun dan daya beli masyarakat menurun sehingga pendapatan pengusaha turun. Turunnya pendapatan pengusaha menyebabkan turunnya kemampuan dalam membayar kewajiban kepada bank. Keadaan ini bisa dilihat dari turunnya prosentase ROA dan ROE bank syariah dan bank konvensional dibanding tahun sebelumnya.

Tabel 3. Perbandingan Rasio Keuangan Bank Syariah dan Bank Konvensional (Persen)

\begin{tabular}{|l|r|r|r|r|r|r|r|r|r|r|}
\hline \multirow{2}{*}{} & \multicolumn{2}{|c|}{2005} & \multicolumn{2}{c|}{2006} & \multicolumn{2}{c|}{2007} & \multicolumn{2}{c|}{2008} & \multicolumn{2}{c|}{2009} \\
\cline { 2 - 11 } & BS & BK & BS & BK & BS & BK & BS & BK & BS & BK \\
\hline ROA & 1.35 & 2.33 & 1.55 & 2.64 & 2.07 & 2.78 & 1.42 & 2.33 & 2.15 & 2.76 \\
\hline ROE & 26.71 & 21.18 & 36.94 & 22.11 & 53.91 & 23.61 & 37.94 & 20.21 & 54.78 & 25.15 \\
\hline NPF & 2.82 & 7.56 & 4.75 & 6.07 & 4.05 & 4.07 & 3.95 & 3.32 & 4.61 & 4.17 \\
\hline FDR & 97.75 & 59.66 & 98.90 & 61.56 & 99.76 & 66.32 & 103.65 & 74.58 & 100.50 & 73.08 \\
\hline BOPO & 78.91 & 89.50 & 76.54 & 86.98 & 76.54 & 84.05 & 81.75 & 88.59 & 74.61 & 90.68 \\
\hline
\end{tabular}

Catatan: tahun 2009 mengunakan data Maret 2009. Sumber: Bank Indonesia, 2009.

Di lain pihak, tingkat rasio pembiayaan terhadap deposit atau FDR bank syariah dan bank konvensional meningkat di akhir 2008. Tingkat FDR bank syariah lebih tinggi dibanding dengan konvensional. Keadaan ini menunjukkan bahwa tingkat dana yang keluar untuk pembiayaan lebih tinggi dibanding dengan dana yang masuk di bank syariah. Artinya ekspektasi keuntungan lebih tinggi bank syariah dibanding dengan bank konvensional walaupun resiko likuiditas yang ditunjukkan dengan tingkat FDR bank syariah lebih tinggi walaupun masih dalam tingkat ideal antara 85\% sampai $110 \%$.

Krisis keuangan menjadikan tingkat pengembalian pembiayaan meningkat. Tingkat kredit macet bank syariah turun di tahun 2008 dibanding tahun 
Heri Sudarsono: Dampak Krisis Kenangan Global...

sebelumnya. Hal ini membuktikan bahwa krisis keuangan tidak berdampak pada kemampuan pengusaha untuk membayarkan kewajibannya di bank syariah. Hal ini disebabkan tingkat margin pada pembiayaan bank syairah tidak berubah selama krisis berlangsung, berbeda dengan bunga yang bisa berubah setiap saat. Meningkatnya tingkat bunga tidak disertai dengan tingkat margin menjadikan tingkat NPL bank syairah menurun di akhir tahun 2008. Di samping itu rata-rata NPL bank syariah masih di bawah 5\%, artinya bank syariah mampu mengatasi kesulitan likuiditas dibanding dengan bank konvensional.

Kondisi bank syariah dalam krisis keuangan global yang ditunjukan dalam perkembangan dari tahun 2005 sampai 2009 menunjukkan adanya kenaikan pada tingkat imbalan/fee/bonus/bagi hasil di akhir tahun 2008. Seiring dengan kenaikan tingkat imbalan/fee/bonus/bagi hasil, tingkat penyaluran pembiayaan semakin tinggi namun masih dalam batas yang aman. Sementara itu, krisis keuangan membuat bank konvensional meningkatkan tingkat bunga guna mengurangi jumlah uang beredar. Namun tingkat pengembalian pinjaman pada bank konvensional yang terlihat dari NPL menunjukkan bahwa bank konvensional kurang berhati-hati dalam menyalurkan pinjaman. Tingkat NPL bank konvensional melebihi batas $5 \%$ sebagai batas aman.

Sementara itu, tingkat efisiensi bank yang ditunjukkan oleh rasio operasional biaya dengan pendapatan operasional (BOPO) memperlihatkan bank syariah lebih efisien dibandingkan dengan bank konvensional. Tingkat BOPO bank konvensional dari tahun 2005 lebih dari $80 \%$, sementara itu bank syariah pada tahun 2008 menunjukkan nilai kurang dari 80\%. Padahal idealnya nilai BOPO antara $60 \%$ sampai $80 \%$, tingginya biaya pada bank konvensional menunjukkan target pendapatan bank konvesional yang tidak terpenuhi. Apalagi pada saat krisis keuangan berlangsung, beban cost of fund semakin tinggi dan menurunnya kemampuan peminjam untuk mengembalikan pinjamannya.

\section{Penutup}

Krisis keuangan global mempengaruhi kondisi perbankan di Indonesia. Bank syariah yang mengunakan sistem jual beli dan bagi hasil menunjukkan kondisi yang berbeda dengan bank konvensional yang mengunakan bunga. Dampak krisis keuangan yang menyebabkan kenaikan tingkat bunga mempengaruhi likuiditas bank konvensional. Sementara itu, tingkat margin dan bagi hasil bank syariah tidak terpengaruh langsung dengan adanya kenaikan BI rate karena tidak akan berubah selama waktu kontrak belum selesai dan untuk mengubahnya harus melalui kontrak baru yang disepakati kedua belah pihak.

Krisis keuangan mempengaruhi kenaikan tingkat bunga simpanan dan pinjaman di bank konvensional dan bank syariah. Tingkat rata-rata tingkat bunga bank konvensional lebih tinggi dibanding dengan tingkat margin di bank syariah. Sementara itu kinerja keuangan kedua bank ini berbeda. Krisis keuangan 2008 menjadikan tingkat pendapatan yang diperoleh berkurang. Secara umum kenaikan pendapatan bank syairah lebih tinggi dibandingkan dengan bank konvensional. Sebaliknya, nilai pendapatan dibandingkan aset menunjukkan bank konvensional lebih tinggi. 
Heri Sudarsono: Dampak Krisis Kenangan Global...

Tingkat kemampuan nasabah membayar kewajiban yang diperlihat dari NPF dalam kondisi krisis menunjukkan penurunan di bank syariah, artinya tingkat resiko pinjaman/pembiayaan bermasalah di bank syariah menurun di saat krisis keuangan. Di saat yang sama jumlah FDR bank syariah meningkat. Hal ini menindikasikan bahwa di saat krisis pembiayaan bank syariah lebih murah dibandingkan dengan bank konvensional.

Secara umum bisa disimpulkan bahwa sistem perbankan syariah lebih stabil dibandingkan dengan bank konvensional dalam menghadapi krisis keuangan global. Sistem keuangan syariah yang tidak mengenal bunga menjadikan bank syariah mampu bertahan dari fluktuasi tingkat bunga yang disebabkan oleh turunnya nilai rupiah yang disebabkan langkanya dolar di pasar. Selain itu, kinerja keuangan bank syariah dibandingkan dengan bank konvensional menunjukkan kondisi keuangan yang konsisten dan efisien.

\section{DAFTAR PUSTAKA}

Chapra, Umer (1985), Towards a Just Monetary System: A Discussion of Money, Banking, and Monetary Policy in the Light of Islamic Teachings, London: Islamic Foundation.

Demyanyk, Yulita dan Otto Van Hemert (2008), Understanding the Subprime Mortgage Crisis, Working Paper Series. Social Science Electronic Publishing.

H.P Minsky (2008), Economist Who Decode Lending Trends, New York Times, www.nytimes.com diakses pada 3 Juli 2008.

Greenspan, Alan (2008), Greenspan Sees Signs of Credit Crising Easing, Stock \& Economy-MSNBC.

Lewis, Holden (2007), Moral Hazard Helps Shape Mortgage Mess, dikutip dari www.bankrate.com.

Mian, Atif, dan Amir Sufi (2008), "The Consequences of Mortgage Credit Expansion: Evidence from the 2007 Mortgage Default Crisis", dikutip dari http://ssrn.com/abstract $=1072304$, diakses pada Januari 2009.

Miskhin, Frederic (1997), "The Causes and Propagation of Financial Instability: Lessons for Policymakers", dalam Federal Reserve Bank of Kansas City (1937), Maintaining Financial Stability in a Global Economy, Proceedings of a Symposium Sponsored by the FRB Kansas City, Jackson Hole, Wyoming, August 28-30, pp.55-96.

Stigliz, E., Joseph(2003), The Roaring Nineties: A New History of the World's Most Prosperous Decade, New York: Norton. 